\title{
Dehydroxylation of Perlite and Vermiculite: Impact on Improving the Knock-Out Properties of Moulding and Core Sand with an Inorganic Binder
}

\author{
Artur Bobrowski ${ }^{1, *}$, Karolina Kaczmarska ${ }^{1}\left(\mathbb{D}\right.$, Maciej Sitarz ${ }^{2} @$, Dariusz Drożyński ${ }^{1}$, Magdalena Leśniak ${ }^{2}{ }^{\circledR}$, \\ Beata Grabowska ${ }^{1}$ (D) and Daniel Nowak ${ }^{3}$ (D) \\ 1 Faculty of Foundry Engineering, AGH-University of Science and Technology, Reymonta 23, 30059 Krakow \\ Poland; karolina.kaczmarska@agh.edu.pl (K.K.); dd@agh.edu.pl (D.D.); beata.grabowska@agh.edu.pl (B.G.) \\ 2 Faculty of Materials Science and Ceramics, AGH_University of Science and Technology, Mickiewicza 30, \\ 30059 Krakow, Poland; msitarz@agh.edu.pl (M.S.); mlesniak@agh.edu.pl (M.L.) \\ 3 Faculty of Mechanical Engineering, Wroclaw University of Science and Technology, 27 Wybrzeże \\ Wyspiańskiego, 50370 Wrocław, Poland; daniel.nowak@pwr.edu.pl \\ * Correspondence: arturb@agh.edu.pl
}

\section{check for}

updates

Citation: Bobrowski, A.;

Kaczmarska, K.; Sitarz, M.;

Drożyński, D.; Leśniak, M.;

Grabowska, B.; Nowak, D.

Dehydroxylation of Perlite and

Vermiculite: Impact on Improving the Knock-Out Properties of Moulding and Core Sand with an Inorganic Binder. Materials 2021, 14, 2946. https://doi.org/10.3390/ma14112946

Academic Editor: Tomasz Wróbel

Received: 22 March 2021

Accepted: 26 May 2021

Published: 29 May 2021

Publisher's Note: MDPI stays neutral with regard to jurisdictional claims in published maps and institutional affiliations.

Copyright: (c) 2021 by the authors. Licensee MDPI, Basel, Switzerland. This article is an open access article distributed under the terms and conditions of the Creative Commons Attribution (CC BY) license (https:/ / creativecommons.org/licenses/by/ $4.0 /)$.
Abstract: The article presents the results of research aimed at examining the type of swelling material introduced into moulding or core sand to improve their knock-out properties. Tests on Slovak perlite ore (three grain sizes), Hungarian perlite ore and ground vermiculite (South Africa) were carried out. For this purpose, thermal and structural analyses (FTIR-Fourier Transform Infrared Spectroscopy), a chemical composition test (XRF-X-Ray Fluorescence), phase analysis (XRD-X-Ray Diffraction), and scanning electron microscopy (SEM-Scanning Electron Microscope) as well as final strength tests of moulding sands with the addition of perlite ore and vermiculite were carried out. The results of thermal studies were related to IR (Infrared Spectroscopy) spectra and XRD diffractograms. It has been shown that the water content in the pearlite ore is almost three times lower than in vermiculite, but the process of its removal is different. Moreover, the chemical composition of the perlite ore, in particular the alkali content and its grain size, may influence its structure. The phenomena of expansion (perlite) and peeling (vermiculite) have a positive effect on the reduction of the final sand strength and eliminate technological inconveniences (poor knocking out) that significantly limit the wide use of moulding sands with inorganic binders.

Keywords: aluminosilicate; perlite; vermiculite; dehydroxylation; thermal analysis; FTIR; XRD; XRF; SEM; moulding sand; inorganic binder

\section{Introduction}

The current state of knowledge indicates that many attempts have been made to eliminate the main technological disadvantage, which is poor knock-out property, that limits the wide use of moulding sands with inorganic binders in a foundry. Taking into consideration the increasing requirements and limitations of environmental protection regulations, it can be predicted that the competitiveness of this type of binder in relation to organic binders will increase. Their wide use is supported by the possibility of obtaining good technological and mechanical properties, the purchase price, much lower than that of organic binders, as well as a small amount of harmful products of thermal decomposition (in the form of gases) generated when pouring molds with a liquid casting alloy and lower costs of waste disposal [1,2]. In addition, the foundries also bear costs related to environmental fees, the amount of which strongly depends on the quantity and quality of generated waste, including gas products. The assessment of the harmfulness of moulding sand does not only concern emissions to the atmosphere. What should also be remembered are the work environment and the frequent exposure of workers to large amounts of harmful substances. To increase the competitiveness and interest of the foundries in 
inorganic binders, it seems necessary to eliminate or significantly reduce poor knock-out properties. They are the result of the so-called second maximum strength resulting from exposure to a high temperature [3,4]. Many attempts have been made to improve the knockout properties with the use of various types of materials or by modifying the structure of inorganic binders, e.g., by introducing metal oxides. All these measures were aimed at reducing the final strength of the moulding sand and thus led to an improvement in the knock-out properties [5-13].

Knowing the characteristic feature of commonly available materials of mineral origin (perlite ore, vermiculite), which is the increase in volume under the influence of temperature (expansion and exfoliation phenomena), associated with the high speed dehydroxylation reaction [14-18], it was assumed that their introduction into moulding or core sand would reduce the final sand strength and would reduce the technological inconvenience associated with poor knock-out properties. The kinetic energy of the swelling additive located between the grains of the grain matrix will disrupt the continuity of the hardened binder layer and contribute to loosening of the hardened sand and lowering the final strength. Thanks to this, the knock-out will also be improved. Because the minerals belong to the group of inorganic materials, they will not emit harmful gaseous products during heating. In this way, it becomes possible to preserve the basic advantage of sands with inorganic binders - they will remain environmentally friendly.

Based on a literature review, it was found that Greek perlite (Milos Island) is the best studied perlite deposit in Europe [19-21]. The paper [21] compares the chemical compositions of Greek, Italian, Hungarian, Chinese, and Turkish perlites and describes the impact of heat treatment processes on changes in IR spectra. However, there is no reference to Slovak perlite and the relationship between the chemical composition and phase changes under the influence of temperature and the results of FTIR structural studies. In the publication [22] on the Slovak perlite ore from the Lehôtka deposit near Brehmi, it was shown that it mainly contains biotite, albite, quartz, and smectite, but the influence of the ore grain size on any changes in the phase composition or changes taking place in the pearlite ore under the influence of temperature (dehydroxylation, chemical composition, phase transitions) have not been described. No detailed studies were found for thermal, structural, and phase analyses for perlite ore from Hungarian deposits beyond the chemical composition listed in [21].

In the works [23-25], thermal properties of natural vermiculite were determined. The publication $[23,24]$ concerned the Santa Olalla vermiculite deposit (Huelva, Spain), and tests on samples before and after grinding in a vibratory mill were carried out. In turn, in the publication [25], the authors, referring to the obtained research results, stated that, in their opinion, this process was not sufficiently explained, and therefore a detailed characterization of the structural evolution during the dehydration of high-purity raw vermiculite from the Chinese deposit in Hebei Province using the XRD method in-situ was carried out.

Earlier studies of South African vermiculite from the Palabora deposit showed that it is not pure, as the content of potassium oxide $\left(\mathrm{K}_{2} \mathrm{O}\right)$ is higher than $0.35 \%$ [26] and contains relatively high levels of iron [27]. It is considered to be one of the most environmentally friendly due to the fact that it is free of asbestos-like fibers and free crystalline silica [28], which is extremely important for the preparation of moulding sand.

In the literature, one can find work on reducing the final strength of moulding sand with an inorganic binder with the use of mineral additives, where the sand was introduced with an additive named Glassex, which is expanded perlite $[4,7,10]$. A significant gap is the lack of data on the effect of perlite ore with a different grain size and type of deposit on the ability to reduce the final strength of moulding and core sand, and thus improve its knock-out properties. There is also no comparison on the difference between the final strength of moulding sands with an inorganic binder if, at the stage of their preparation, perlite or vermiculite ore is added. 
According to the authors, the results contained in the publication supplement the knowledge available so far.

\section{Materials and Methods}

\subsection{General Characteristics of Materials}

Perlite ore from Slovak deposits (SP1-SP3 samples; Perlit AF Sp. Z o.o., Kazimierz Biskupi, Poland) of various grain sizes, Hungarian perlite ore (HP sample; Perlit AF Sp. Z o.o., Kazimierz Biskupi, Poland), and South African vermiculite (V; Vermiculite Poland, Ełk, Poland) were used for the tests. The moulding sands for determination of the tensile strength $\left(R_{m}^{t k}\right)$ according to the following protocol was carried out:

- Moulding sand without additives (G) — quartz sand form Szczakowa mine, Sibelco Poland (Bukowno, Poland) $\left(97.28 \%\right.$ ), inorganic Geopol ${ }^{\circledR}$ binder form Sand Team S.r.o, Holubice, Czech Republic) (2.43\%), ester hardener SA72 form Sand Team S.r.o, Holubice, Czech Republic (0.29\%);

- Moulding sand with perlite ore (SP1-SP3 and HP)— quartz sand form Szczakowa mine, Sibelco Poland (Bukowno, Poland) $(95.42 \%)$, inorganic Geopol ${ }^{\circledR}$ binder form Sand Team S.r.o, Holubice, Czech Republic (2.38\%), ester hardener SA72 form Sand Team S.r.o, Holubice, Czech Republic (0.29\%), perlite ore (1.91\%);

- Moulding sand with vermiculite (V)—quartz sand form Szczakowa mine, Sibelco Poland (Bukowno, Poland) $\left(96.34 \%\right.$ ), inorganic Geopol ${ }^{\circledR}$ binder form Sand Team S.r.o, Holubice, Czech Republic (2.41\%), ester hardener SA72 form Sand Team S.r.o, Holubice, Czech Republic (0.29\%), vermiculite $(0.96 \%)$.

\subsubsection{Perlite Ore}

Perlite ore is a transformed effusive rock built of volcanic glass, whose name comes from the French "pearl" (in German "Perlstein"), and is connected with the ball (pearl) form. This form is a result of the stresses caused by the rapid cooling of the glaze. Perlite ore also has a characteristic color and gloss $[16,29,30]$. Chemically, the perlite is a metastable, amorphous, hydrated potassium-sodium aluminosilicate with a cryptocrystalline structure. In the structure of perlite, apart from chemically bound water, the content of which usually ranges from 2.0 to $5.0 \%$ by volume, there may also be quartz inclusions, plagioclase, biotite, and secondary minerals such as montmorillonite or zeolite [30,31]. Deposits of the Slovak perlite are found in tertiary rocks in volcanic areas in the central and eastern part of Slovakia. They are a part of a complex of rocks made of tuffs, rhyolites, and andesites. The resources of these deposits are estimated at over 30 million tons [14]. The tested samples came from the Lehôtka deposit. In turn, Hungarian perlite belongs to the group of Upper Miocene rocks of the rhyolite-rhyodacite type. It was created as a result of undersea volcanic activity on the edge of a subduction zone, with very acidic viscous lava and pyroclastic materials. This ore contains $90-95 \%$ of amorphous volcanic glaze, 5.0 to $6.0 \%$ of crystalline components, mainly quartz, plagioclase, biotite, and $2.5-3.5 \%$ of water $[14,32]$. Despite comparable prices of these raw materials, perlite from the Hungarian deposits differs from the Slovak perlite ore in terms of properties of the obtained expanded perlite. The Slovak perlite is characterized by a creamier color, higher density, and higher mechanical strength. On the other hand, the Hungarian perlite ore is characterized by a very fine graining and lower mechanical strength [14].

\subsubsection{Vermiculite}

The name "vermiculite" comes from the Latin word vermiculus and means "worm". Thus, it refers to the characteristic appearance of the mineral after its rapid heating. Then, the conversion of its internal layers occurs due to the separation of the inter-packet water. The evaporation of the water results in a 15- to 30-fold increase in volume. This process is called exfoliation, i.e., the separation of layers (plates) in grains, and is carried out at a temperature of about $900-1000{ }^{\circ} \mathrm{C}$. Its effect is to increase the volume while reducing the apparent and bulk density [33-37]. In the case of some vermiculites, the beginning 
of the exfoliation process can be observed at a temperature of $300{ }^{\circ} \mathrm{C}$ [36]. As shown in previous studies [34], as a result of rapid heating to $100{ }^{\circ} \mathrm{C}$, vermiculite loses about $50 \%$ of the interlayer water, but at this temperature, the layer separation process (exfoliation) does not occur. The vermiculite $\left((\mathrm{Mg}, \mathrm{Fe}, \mathrm{Al})_{3}(\mathrm{Al}, \mathrm{Si})_{4} \mathrm{O}_{10}(\mathrm{OH})_{2} \cdot 4 \mathrm{H}_{2} \mathrm{O}\right)$ belongs to the group of clay minerals, which belong to the group of 2:1 type phyllosilicate packets, where the octahedron layer is closed between two tetrahedron layers, vertices facing each other [34,37-41]. Vermiculite is formed as a result of the hydrolysis and weathering of magma packet rocks, hydrothermal action, seepage of groundwater or a combination of these three factors, from dark types of biotite, hydrobiotite, and phlogopite belonging to the mica group [34-36,42]. Vermiculite is very rarely present as a pure component, and most often it forms mosaic-like mixed-pack structures. Depending on the deposit and its impurities, its color ranges from yellow-golden, brown to olive [34,43-45].

\subsection{Characterization of Methods}

The following devices and research methodology were used in the research:

- The perlite ore samples did not require preparation. In turn, vermiculite was subjected to the process of grinding (comminuting) in a ball mill in order to obtain a fine-grained fraction, because only the material prepared in this way is suitable for use in moulding sands.

- Sieve analysis on a standard set with a mesh size from 0.056 to $1.6 \mathrm{~mm}$ (average of two measurements), in accordance with the Polish Standard (PN-85/H-11001) was carried out.

- Simultaneous TG/DTG/DTA (Thermal Gravimetry/Differential Thermal Gravimetry/Differential Thermal Analysis) thermal examinations of the tested materials were performed with use of the Thermal Analyzer produced by Jota (Kraków, Poland). The temperature range of test was $20-1000{ }^{\circ} \mathrm{C}$, and the heating rate was $10{ }^{\circ} \mathrm{C} / \mathrm{min}$ in an air atmosphere in alumina pans.

- Structural studies were carried out by means of infrared spectroscopy (FTIR) by a transmission technique consisting of preparing pellets in potassium bromide $(\mathrm{KBr})$, using an Digilab Excalibur FTS 3000 (Bio Rad, Hercules, CA, USA) spectrometer with a standard DTGS detector. The spectra were recorded in the Resolution Pro (Varian/Agilent Technologies, Santa Clara, CA, USA) program in the specific infrared range (4000-400 $\left.\mathrm{cm}^{-1}\right)$, with a resolution of $4 \mathrm{~cm}^{-1}$. In order to obtain the appropriate quality of the spectra, the samples were ground in the form of fine powder in agate mortars and then mixed with $\mathrm{KBr}$ in the ratio 1:100. Test material samples were obtained as a result of rapid heating in a silite furnace at a temperature in the range of $100-1000{ }^{\circ} \mathrm{C}$. The residence time of the sample in the oven was $10 \mathrm{~min}$ in each case.

- The chemical composition of the investigated materials was determined by the X-ray Fluorescence Spectrometry (XRF) method, using a WD-XRF Axios Max spectrometer with Rh 4 kW PANalytical lamp (Malvern Panalytical, Malvern, UK).

- To analyze the phase composition of the materials, a Philips/Panalytical X'Pert Pro MD powder diffractometer (Malvern Panalytical, Malvern, UK) using $\mathrm{Cu} \mathrm{K} \alpha 1$ radiation was used. Standard Bragg-Brentano geometry with a $\theta-2 \theta$ setup was applied $\left(0.008^{\circ}\right.$ step size and $5-90^{\circ} 2 \theta$ range). Highscore Plus 3.0 software with a database (Version: PDF-4+2021 powder diffraction database, 2021, International Centre for Diffraction Data, Newtown Square, Pennsylvania, USA) was used to determine the positions of the observed peaks and assign them to the appropriate phases. 
- Moulding sands with an inorganic geopolymer binder were prepared in a roller mixer. First, sand without additives (without perlite ore and vermiculite) was prepared, which was the reference point. Then, the moulding sands with additives were prepared. The mixing time was $5 \mathrm{~min}$ in each case. The loose components, i.e., the grain matrix (quartz sand) and the perlite ore/ground vermiculite (mixing time $1 \mathrm{~min}$ ) were mixed first, then the SA72 hardener (Sand Team S.r.o, Holubice, Czech Republic) (mixing time $1 \mathrm{~min}$ ) was added, and the (Geopol binder Sand Team S.r.o, Holubice, Czech Republic) (mixing time $3 \mathrm{~min}$ ) was added in the last stage.

- Standard fittings for determining the tensile strength were made of the prepared sands. A portion of the moulding sand was placed in a special matrix, coupled with a device for a vibratory concentration of samples (LUZ-2e apparatus manufactured by Multiserw Morek, Brzeźnica, Poland). The hardening process in the open air, under laboratory conditions (temperature $20-21{ }^{\circ} \mathrm{C}$, relative humidity $30-35 \%$ ) was carried out. After hardening the moulding sand (within $24 \mathrm{~h}$ ), the samples were heated together in the furnace to a temperature in the range of $100-1000{ }^{\circ} \mathrm{C}$, with a heating rate of $10^{\circ} \mathrm{C} / \mathrm{min}$ (the same as in the case of the thermal analysis). After the sand samples and the furnace had cooled down to the ambient temperature, the tensile strength $\left(R_{m}^{t k}\right)$ was determined using the LRu-2 moulding sand strength tester (Multiserw-Morek, Brzeźnica, Poland). Moulding sand without additives (as a reference point) $(G)$, sands with the addition of the Slovak perlite ore of various grain sizes (SP1-SP3), the Hungary perlite ore (HP), and crushed vermiculite (ground) (V) were also made.

- Microscopic images of moulding sands with additives were made with the use of a HITACHI TM-3000. A Hitachi TM3000 scanning electron microscope (SEM) (Hitachi High-Tech Co., LTD, Tokyo, Japan) was used in this study to investigate the surface morphology of specimens, with a $30 \mathrm{~nm}$ resolution, a charge reduction mode of 5 or $15 \mathrm{kV}$ voltage, and $15 \times$ to $30,000 \times$ magnification capabilities. For high-resolution imaging, the samples were carbon sprayed using a Quorum Techologies Q150T high vacuum sputter (Lewes, UK).

\section{Results and Discussion}

\subsection{Sieve Analysis}

In the first stage of the research, sieve analysis of materials was carried out. Tables 1 and 2 show their grain size composition and a comparison of the basic grain size parameters.

Table 1. Grain size analysis of Slovak perlite ore (SP1-SP3), Hungarian perlite ore (HP), ground vermiculite (V) and quartz sand (QS - matrix of moulding sands).

\begin{tabular}{ccccccc}
\hline \multirow{2}{*}{ Mesh Size Sieve } & \multicolumn{7}{c}{ Material } \\
\cline { 2 - 7 } & SP1 & SP2 & SP3 & HP & V & QS \\
\hline 1.600 & 0.00 & 0.00 & 0.00 & 0.00 & 0.00 & 0.00 \\
0.800 & 0.00 & 0.00 & $\mathbf{0 . 9 5}$ & 0.00 & 0.00 & 0.00 \\
0.630 & 0.00 & 0.00 & $\mathbf{1 . 5 8}$ & 1.84 & 0.00 & 0.48 \\
0.400 & 0.00 & $\mathbf{4 8 . 1 6}$ & $\mathbf{2 9 . 9 8}$ & $\mathbf{3 0 . 0 8}$ & 0.06 & 7.19 \\
0.320 & 0.00 & $\mathbf{3 0 . 2 1}$ & 40.10 & $\mathbf{2 0 . 6 2}$ & 0.13 & $\mathbf{1 8 . 6 3}$ \\
0.200 & 0.00 & $\mathbf{1 1 . 5 8}$ & 25.94 & $\mathbf{2 9 . 0 9}$ & 3.36 & $\mathbf{5 0 . 2 1}$ \\
0.160 & 6.52 & 4.38 & 0.31 & 7.93 & 9.83 & $\mathbf{1 3 . 1 0}$ \\
0.100 & 9.29 & 4.10 & 0.38 & 7.36 & 22.54 & 9.71 \\
0.071 & $\mathbf{9 . 3 5}$ & 0.67 & 0.20 & 1.22 & $\mathbf{1 3 . 3 4}$ & 0.56 \\
0.056 & $\mathbf{2 2 . 0 3}$ & 0.33 & 0.20 & 0.53 & $\mathbf{3 . 6 6}$ & 0.07 \\
Bottom & $\mathbf{5 2 . 8 1}$ & 0.57 & 0.36 & 1.33 & $\mathbf{4 7 . 0 8}$ & 0.05 \\
Sum & 100.00 & 100.00 & 100.00 & 100.00 & 100.00 & 100.00 \\
\hline
\end{tabular}


Table 2. Comparison of grain size distribution of tested materials.

\begin{tabular}{|c|c|c|c|c|c|c|c|}
\hline \multirow{2}{*}{ Parameter } & \multirow{2}{*}{ Unit } & \multicolumn{5}{|c|}{ Material } & \multirow[b]{2}{*}{ QS } \\
\hline & & SP1 & SP2 & SP3 & HP & $\mathbf{V}$ & \\
\hline Average grain size, $d_{L}$ & $\mathrm{~mm}$ & 0.08 & 0.30 & 0.31 & 0.24 & 0.06 & 0.23 \\
\hline Average grain size, $D_{50}$ & $\mathrm{~mm}$ & 0.10 & 0.40 & 0.36 & 0.33 & 0.07 & 0.26 \\
\hline \multirow{3}{*}{$\begin{array}{l}\text { The mesh size sieve where the main } \\
\text { faction has gathered }\end{array}$} & & $0.071 /$ & $0.40 /$ & $0.40 /$ & $0.40 /$ & $0.071 /$ & $0.32 /$ \\
\hline & - & $0.056 /$ & $0.32 /$ & $0.32 /$ & $0.32 /$ & $0.056 /$ & $0.20 /$ \\
\hline & & bottom & 0.20 & 0.20 & 0.20 & bottom & 0.16 \\
\hline Main fraction, $F_{g}$ & $\%$ & 92.61 & 89.95 & 96.02 & 79.79 & 82.96 & 81.94 \\
\hline Distribution factor, $S_{0}$ & - & 1.27 & 1.20 & 1.19 & 1.38 & 1.93 & 1.27 \\
\hline Inclination indicator, $S_{k}$ & - & 1.04 & 1.04 & 1.05 & 0.93 & 0.98 & 1.00 \\
\hline Homogeneity degree, GG & $\%$ & 61.00 & 68.00 & 74.00 & 50.00 & 21.00 & 68.00 \\
\hline Grain number, $L$ & - & 150.52 & 42.90 & 40.76 & 52.27 & 21.86 & 55.27 \\
\hline
\end{tabular}

\subsection{Thermal Analysis}

Figures 1-3 show the results of the thermal analysis for the Slovak perlite ore of various grain size (SP1-SP3), and Figure 4 shows the results of the determination for the Hungarian perlite ore (HP). In turn, the results of the analysis for ground vermiculite (V) are shown in Figure 5.

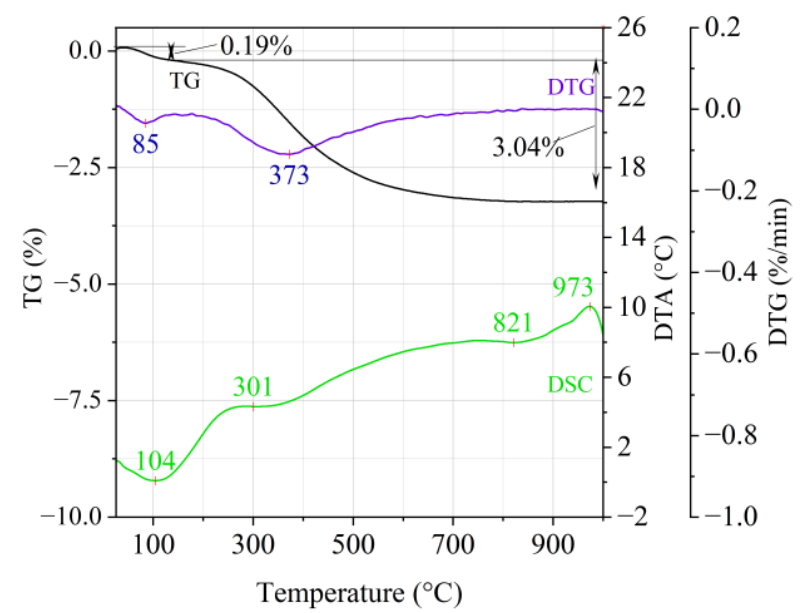

Figure 1. Thermal analysis curves of Slovak perlite ore (SP1).

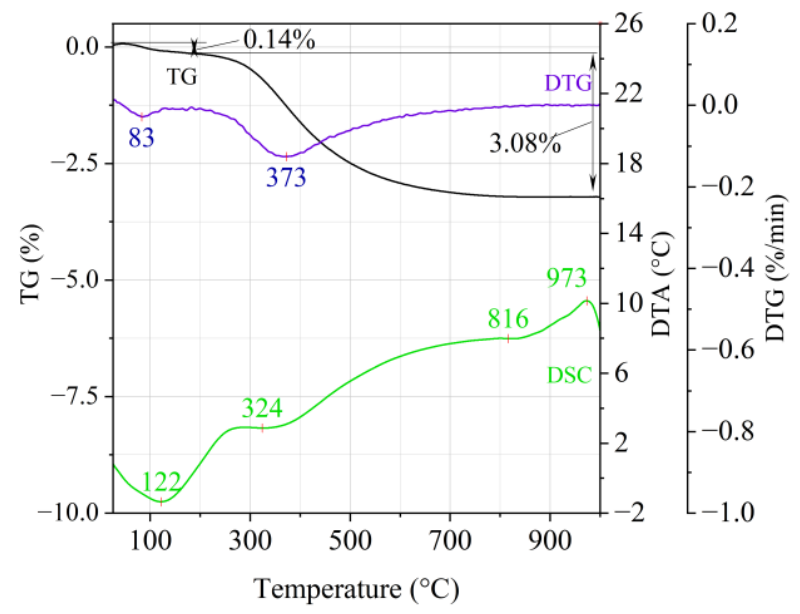

Figure 2. Thermal analysis curves of Slovak perlite ore (SP2). 


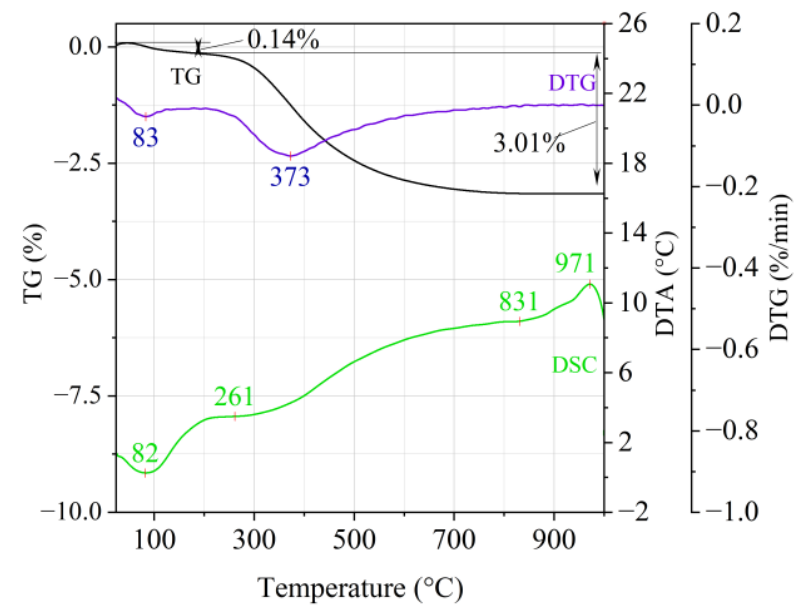

Figure 3. Thermal analysis curves of Slovak perlite ore (SP3).

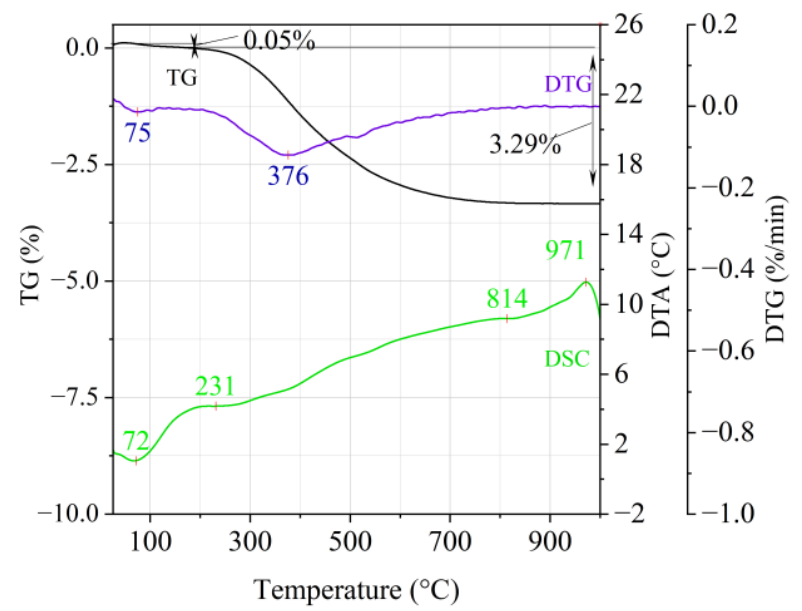

Figure 4. Thermal analysis curves of Hungarian perlite ore (HP).

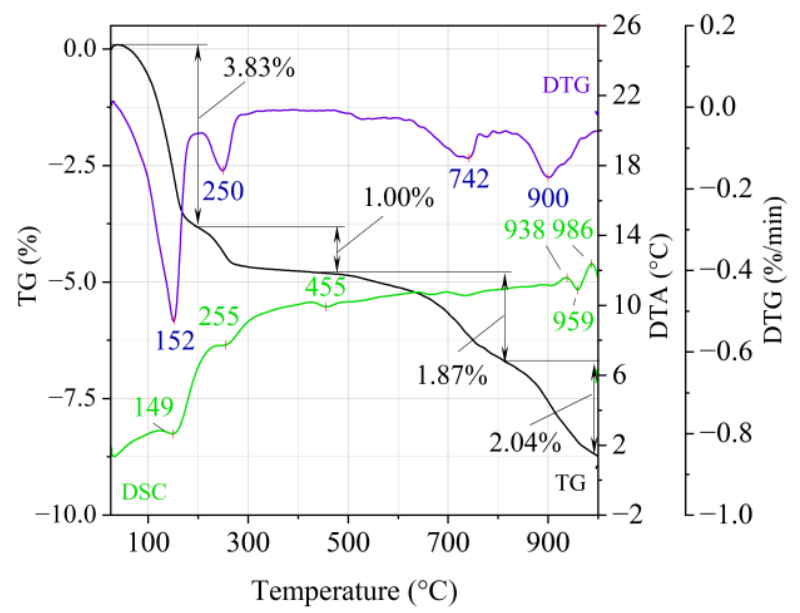

Figure 5. Thermal analysis curves of ground vermiculite (V).

The endothermic effect with a maximum at a temperature of approx. $100{ }^{\circ} \mathrm{C}$ indicates the ongoing dehydration process (weight loss up to $190^{\circ} \mathrm{C}$ ). Slovak perlite ore then loses a small amount of adsorbed water (SP1-0.19\%, SP2-0.14\%, SP3-0.14\%), while Hungarian perlite loses only $0.05 \%$. The temperature of maximum weight loss for SP1-SP3 was approx. $85^{\circ} \mathrm{C}$ and for perlite it was $75^{\circ} \mathrm{C}$. As a result of further heating from $190{ }^{\circ} \mathrm{C}$ to $1000{ }^{\circ} \mathrm{C}$, 
about 3\% weight loss was noted for the Slovak pearlite ore samples. Slightly greater weight loss was recorded for the Hungarian pearlite ore sample, amounting to $3.29 \%$ (Figure 4). The dehydroxylation process takes place over a wide temperature range, which proves the presence of several types of water (free, structural) in the perlite ore structure. The gradual heating is therefore not conducive to the rapid dehydroxylation reaction of the perlite ore associated with a significant increase in volume, as part of the "energy charge" accumulated in the material structure is released in stages. No significant relationship was found between the grain size of Slovak perlite ore (with a different main fraction) and the amount of water accumulated in its structure.

On the TG-DTG curves obtained for the ground vermiculite sample (Figure 5), it is possible to indicate four stages of weight loss. On the DTA curve there are four endothermic and two exothermic effects. At the temperature of $195^{\circ} \mathrm{C}$, there is a first loss of weight about $3.83 \%$ (maximum weight loss rate at $152{ }^{\circ} \mathrm{C}$ ) and it should be related to the reaction of removing the water adsorbed on the surface of the material (endothermic effect at $149^{\circ} \mathrm{C}$ ). A second weight loss was recorded at a temperature range $195-430{ }^{\circ} \mathrm{C}$, which is related to the reaction of removing the inter-packet water and water associated with the cation exchange (endothermic effect with maximum at $255^{\circ} \mathrm{C}$ ). The beginning of the dehydroxylation process, characterized by a slow rate associated with the release of $\mathrm{OH}$ groups bound in the vermiculite structure, occurs at the third and fourth stage of weight loss at temperatures above $500{ }^{\circ} \mathrm{C}$. The third weight loss $(1.87 \%)$ occurs in the range of $500-800{ }^{\circ} \mathrm{C}$ with a maximum weight loss rate at $742{ }^{\circ} \mathrm{C}$. The fourth, in the range of approx. $850-1000{ }^{\circ} \mathrm{C}$ with a maximum weight loss rate at $900^{\circ} \mathrm{C}$, is associated with a weight loss of approx. $2.04 \%$. The appearance of exothermic thermal effects around $940{ }^{\circ} \mathrm{C}$ and $980{ }^{\circ} \mathrm{C}$ indicates a change in the initial structure of the vermiculite and the crystallization of a new phase. Between them, an endothermic heat effect (approx. $959^{\circ} \mathrm{C}$ ) was recorded, which may indicate dehydroxylation of the residual hydroxyl groups. These changes inspired the authors to conduct infrared (FTIR) structural research and phase composition analysis (XRD).

\subsection{X-ray Fluorescence Analysis (XRF)}

In order to determine the chemical composition of the starting materials and to properly interpret the results of X-ray diffraction (XRD), tests were performed using X-ray fluorescence spectroscopy (XRF). Tables 3 and 4 show the elemental and oxide compositions, respectively.

Table 3. Elemental composition of the tested materials.

\begin{tabular}{cccccc}
\hline Component & SP1 & SP2 & SP3 & HP & V \\
\hline $\mathrm{O}$ & 47.6 & 47.35 & 48.63 & 48.31 & 39.60 \\
$\mathrm{Si}$ & 33.18 & 33.18 & 33.88 & 34.58 & 15.96 \\
$\mathrm{Al}$ & 6.45 & 6.14 & 7.69 & 6.32 & 3.47 \\
$\mathrm{~K}$ & 5.89 & 6.66 & 3.78 & 5.13 & 7.04 \\
$\mathrm{Fe}$ & 2.72 & 2.65 & 1.43 & 2.05 & 20.90 \\
$\mathrm{Ca}$ & 1.73 & 1.68 & 0.95 & 1.35 & 1.25 \\
$\mathrm{Na}$ & 1.26 & 1.36 & 2.81 & 1.61 & 0.11 \\
$\mathrm{Ti}$ & 0.32 & 0.21 & 0.12 & 0.11 & 1.89 \\
$\mathrm{Mg}$ & 0.30 & 0.16 & 0.37 & 0.08 & 8.61 \\
Others & 1.09 & 0.61 & 0.34 & 0.46 & 1.17 \\
\hline
\end{tabular}


Table 4. Oxide composition of the tested materials.

\begin{tabular}{cccccc}
\hline Component & SP1 & SP2 & SP3 & HP & V \\
\hline $\mathrm{Na} 2 \mathrm{O}$ & 1.70 & 1.84 & 3.79 & 2.18 & 0.14 \\
$\mathrm{MgO}$ & 0.49 & 0.27 & 0.61 & 0.14 & 14.27 \\
$\mathrm{Al2O} 3$ & 12.20 & 11.60 & 14.53 & 11.94 & 6.55 \\
$\mathrm{SiO} 2$ & 70.99 & 70.99 & 72.47 & 73.99 & 34.13 \\
$\mathrm{~K} 2 \mathrm{O}$ & 7.09 & 8.03 & 4.55 & 6.18 & 8.48 \\
$\mathrm{CaO}$ & 2.43 & 2.35 & 1.33 & 1.89 & 1.75 \\
$\mathrm{Fe} 2 \mathrm{O} 3$ & 3.89 & 3.80 & 2.04 & 2.93 & 29.88 \\
$\mathrm{TiO} 2$ & 0.53 & 0.50 & 0.21 & 0.18 & 3.16 \\
Others & 0.68 & 0.62 & 0.47 & 0.57 & 1.64 \\
\hline
\end{tabular}

Based on the analysis of the chemical composition, it was found that the size of the Slovak perlite ore fraction influences the content of some oxides. As indicated in the work [46], the $\mathrm{K}_{2} \mathrm{O} / \mathrm{Na}_{2} \mathrm{O}$ ratio is particularly important from the point of view of the expansion susceptibility of perlite ore. As shown in Table 4 , the $\mathrm{K}_{2} \mathrm{O} / \mathrm{Na}_{2} \mathrm{O}$ ratio for the smallest fraction (SP1) is 4.17, for the average 4.36, and for the coarsest 1.20. On the other hand, for the Hungarian perlite ore, which, according to the grain composition analysis, has the main fraction collected on the same sieves as the medium-grained perlite (SP2), the $\mathrm{K}_{2} \mathrm{O} / \mathrm{Na}_{2} \mathrm{O}$ ratio is 2.83. It should be noted that the content of $\mathrm{K}_{2} \mathrm{O}, \mathrm{CaO}, \mathrm{Fe}_{2} \mathrm{O}_{3}$, and $\mathrm{TiO}_{2}$ oxides decreases with the increase in the grain size of Slovak pearlite, while the share of $\mathrm{SiO}_{2}, \mathrm{Na}_{2} \mathrm{O}$, and $\mathrm{MgO}$ increases. Hungarian perlite has the lowest $\mathrm{MgO}$ and $\mathrm{TiO}_{2}$ contents. Turkish perlite [47] has a similar content of $\mathrm{SiO}_{2}$ (approx. $71 \%$ ) and $\mathrm{Al}_{2} \mathrm{O}_{3}(13 \%)$, but it contains fewer $\mathrm{Fe}_{2} \mathrm{O}_{3}$ inclusions (approx. 1.6\%). Compared to Macedonian perlite [48], which is considered rich in $\mathrm{K}_{2} \mathrm{O}$ and $\mathrm{Na}_{2} \mathrm{O}$ oxides ( $4.21 \%$ and $3.56 \%$, respectively), Slovak and Hungarian perlite in particular has an even higher $\mathrm{K}_{2} \mathrm{O}$ content, even above $8 \%$, in the case of the medium fraction (SP2) and above 7\%-the smallest fraction (SP1).

Ground vermiculite $(\mathrm{V})$ is characterized by a high content of $\mathrm{SiO}_{2}$ and $\mathrm{Fe}_{2} \mathrm{O}_{3}(34.12 \%$ and $29.88 \%$, respectively). It also has a high $\mathrm{K}_{2} \mathrm{O}$ content (approx. $8.5 \%$ ), which is consistent with the literature [37], but the $\mathrm{MgO}$ content is still higher and amounts to $14.27 \%$. Compared to the Iranian vermiculite from the province of Gilan [49], which has a similar $\mathrm{MgO}$ content, a significant difference should be noted in the content of $\mathrm{Al}_{2} \mathrm{O}_{3}$-Iranian $15.70 \%$ in relation to 6.55 and $\mathrm{Fe}_{2} \mathrm{O}_{3}-12.90 \%$ to $29.88 \%$. In the Iranian vermiculite, the content of the remaining components is: $\mathrm{K}_{2} \mathrm{O}=0.97 \%, \mathrm{CaO}=5.70 \%, \mathrm{Na}_{2} \mathrm{O}=0.16 \%$. The $\mathrm{SiO}_{2}$ content is at a similar level.

\subsection{Structural Analysis (FTIR)}

Figures 6-10 show the IR spectra of the tested materials exposed to the temperature in the range of $100-1000^{\circ} \mathrm{C}$ (prepared in an oven).

Based on the IR spectra of Slovak perlite samples, rapidly heated in a furnace at a fixed temperature, it can be concluded that the water removal process runs over a wide temperature range. Initially, there is a visible weakening of the intensity of the band in the wavenumber range $3650-3400 \mathrm{~cm}^{-1}$ and the band occurring around $1640 \mathrm{~cm}^{-1}$. The dehydroxylation process associated with the removal of $\mathrm{OH}$ groups takes place up to the temperature of about $800{ }^{\circ} \mathrm{C}$. For the sample of Slovak perlite with the smallest grain size (SP1), the primary structure of the material decomposed at $1000{ }^{\circ} \mathrm{C}$ (Figure 11). The remaining samples, both Slovak and Hungarian perlite ores, retain their structure, but a change in the half-width of the bands can be indicated as the temperature increases. The analysis of the spectra of vermiculite $(\mathrm{V})$ shows that at $500{ }^{\circ} \mathrm{C}$, water is removed from its structure, which is manifested in the disappearance of the characteristic bands within the wavenumbers $3440 \mathrm{~cm}^{-1}$ (stretching vibrations $\mathrm{vOH}$ ) and $1643 \mathrm{~cm}^{-1}$ (deformation vibrations $\delta \mathrm{OH}$ ). Additionally, at a temperature of $900{ }^{\circ} \mathrm{C}$, changes in its structure begin, initially manifested by the appearance of two bands: at $878 \mathrm{~cm}^{-1}$ and $839 \mathrm{~cm}^{-1}$, along with an increase in their intensity in the spectra of the sample exposed to the temperature 
of $1000{ }^{\circ} \mathrm{C}$ and a clear shift of the maximum intensity of the main band from 1002 to $1032 \mathrm{~cm}^{-1}$, characteristic of Si-O asymmetric stretching vibrations [50,51]. According to literature data [52] at $900{ }^{\circ} \mathrm{C}$ the illite decomposes and enstatite appears, and when heated to $1000{ }^{\circ} \mathrm{C}$, enstatite decomposes and forsterite appears. Such a course is indicated by the appearance of an intense band at $878 \mathrm{~cm}^{-1}$, characteristic of forsterite [53].

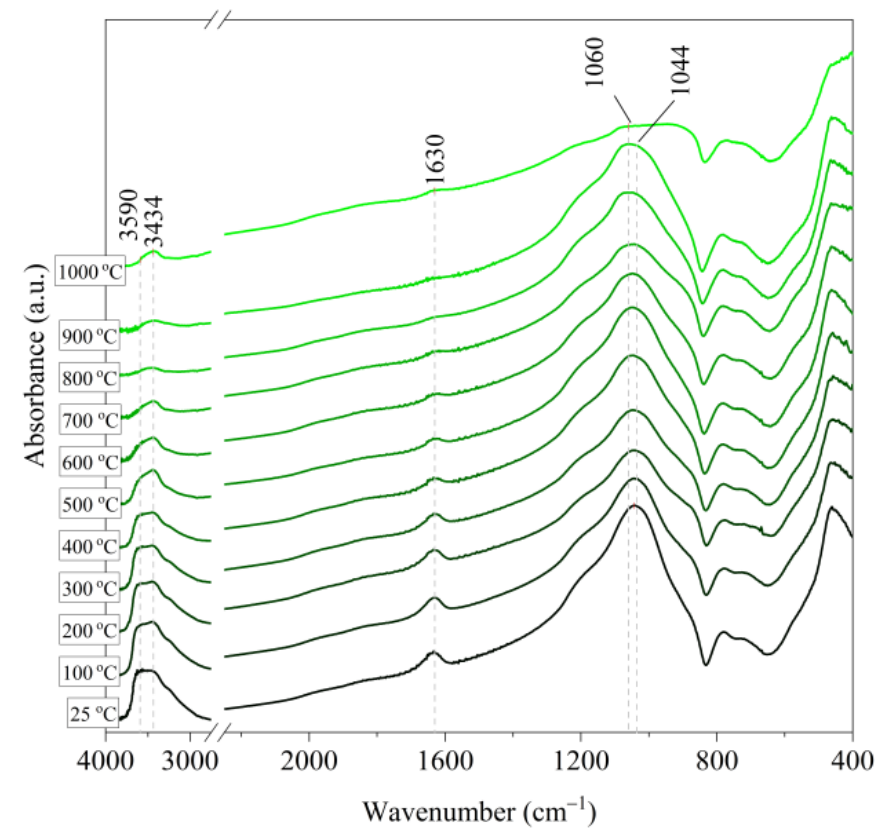

Figure 6. IR spectra of Slovak perlite ore (SP1) after annealing at a temperature in the range of $100-1000{ }^{\circ} \mathrm{C}$.

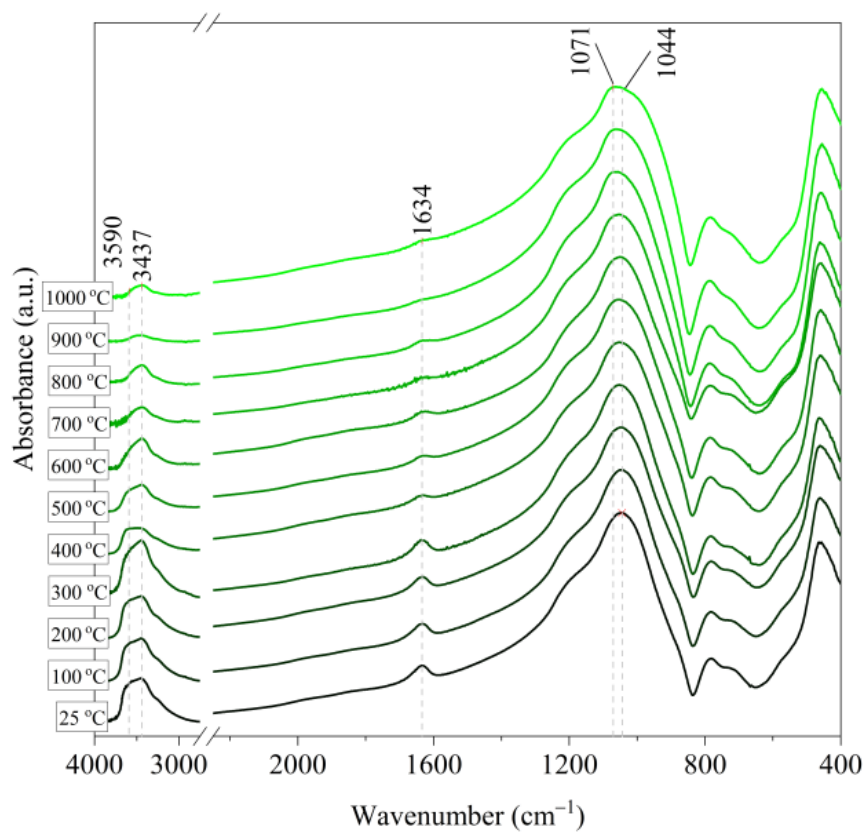

Figure 7. IR spectra of Slovak perlite ore (SP2) after annealing at a temperature in the range of $100-1000{ }^{\circ} \mathrm{C}$. 


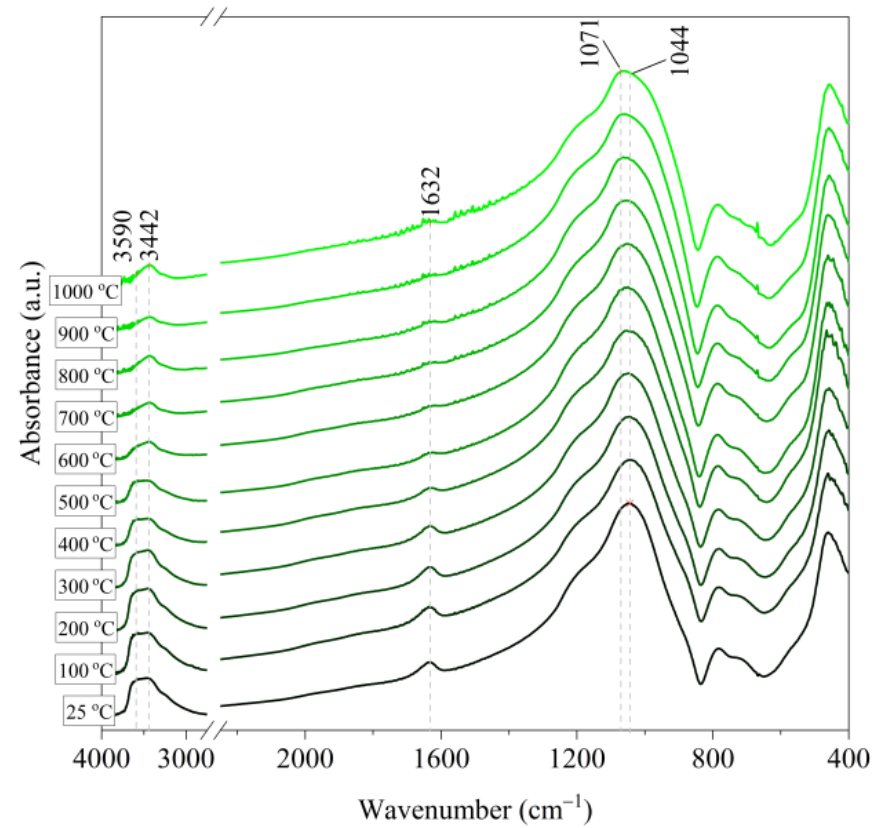

Figure 8. IR spectra of Slovak perlite ore (SP3) after annealing at a temperature in the range of $100-1000{ }^{\circ} \mathrm{C}$.

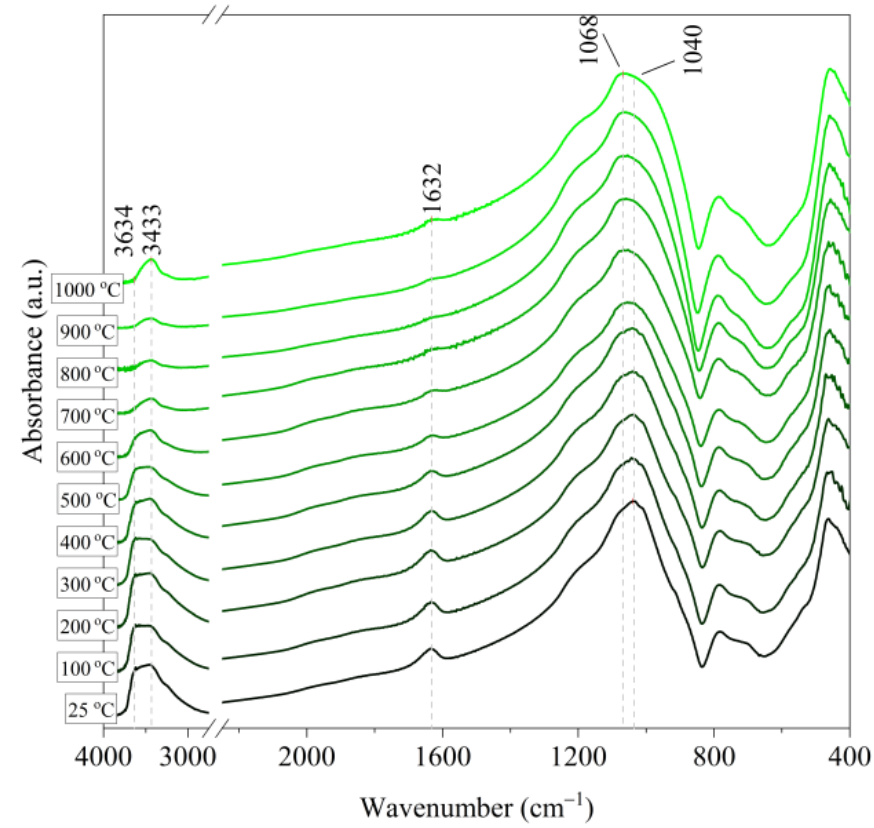

Figure 9. IR spectra of Hungarian perlite ore (HP) after annealing at a temperature in the range of $100-1000{ }^{\circ} \mathrm{C}$. 


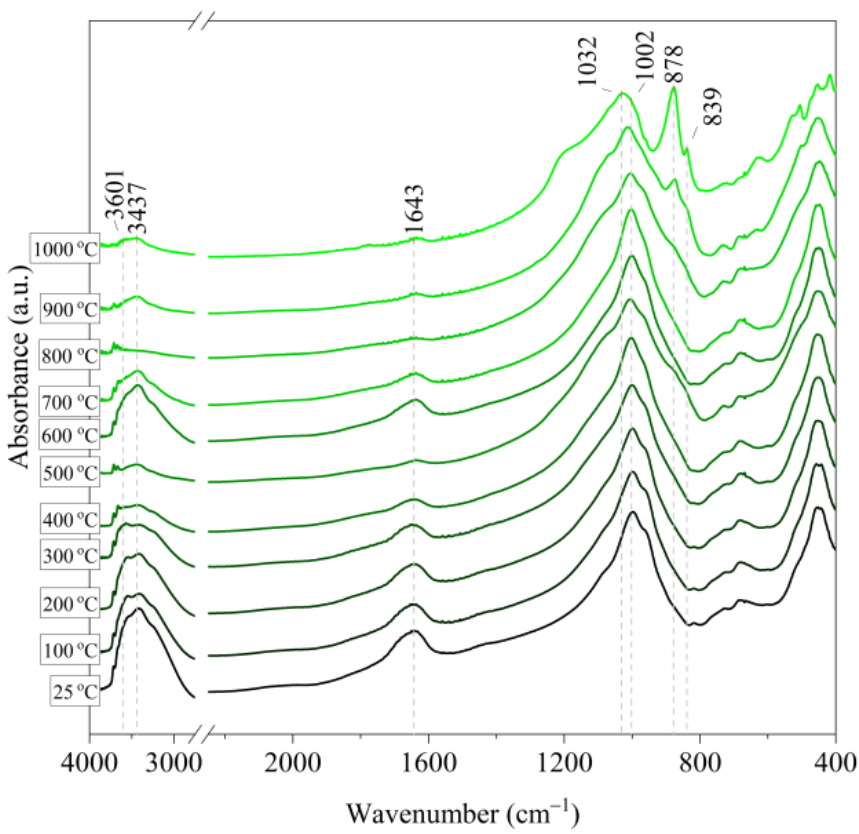

Figure 10. IR spectra of vermiculite (V) after annealing at a temperature in the range of $100-1000^{\circ} \mathrm{C}$.

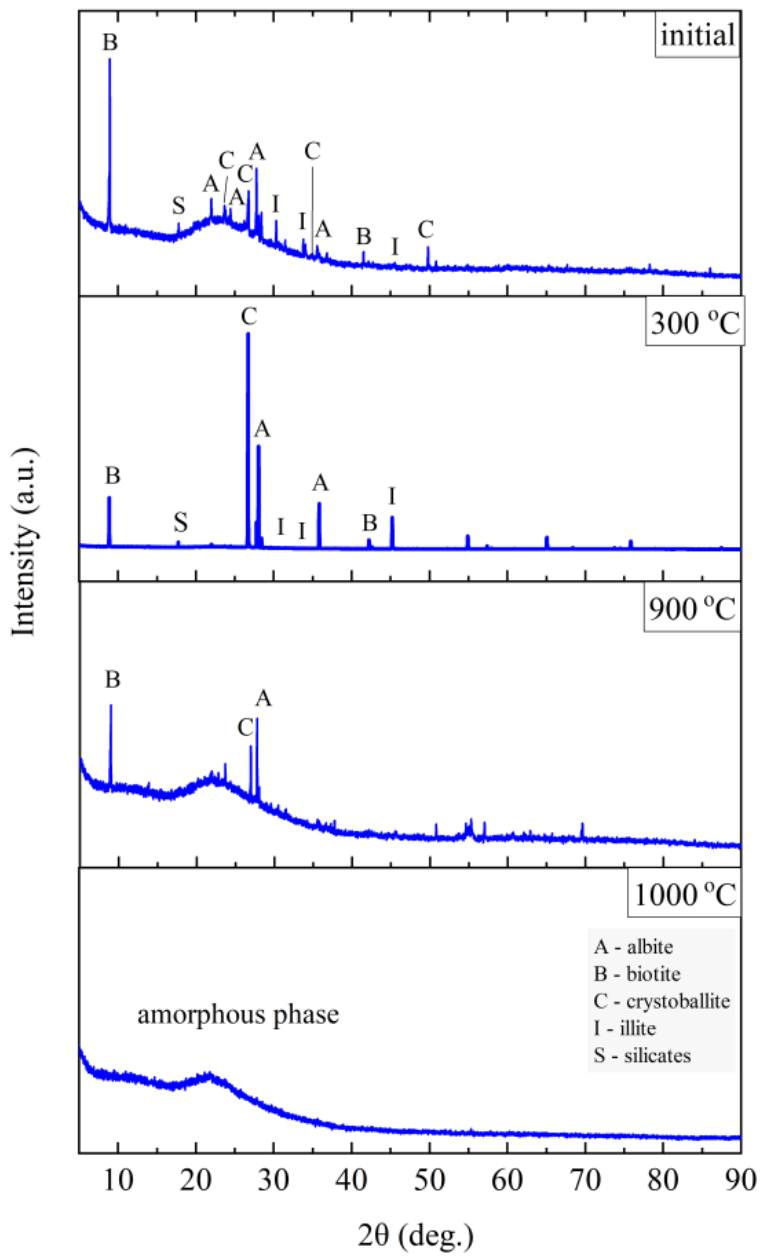

Figure 11. XRD diffractograms for Slovak perlite ore SP1. 


\subsection{Analysis of the Change in the Phase Composition (XRD) under the Influence of Temperature}

Greek perlite (Milos, Tsigrado, and Trachilas fields) was investigated in the publication [20]. XRD analysis of the starting perlite revealed the presence of glassy phase, quartz, feldspar K, plagioclase, and mica. Small amounts of ilmenite, zirconium, and spinel were also identified, but only in the Tsigrado pearlite sample, which were removed in the expansion process. In turn, the publication [19] showed that Greek perlite consists mainly of silicate glass (amorphous) and additives in the form of biotite, quartz, and feldspar. In the case of Macedonian perlite [48], XRD analysis showed the presence of a large amount of aluminosilicate amorphous and small amounts of crystalline, represented mainly by feldspar, quartz, and cristobalite. Feldspar is represented as K-plagioclase, Na-feldspar, and microcline. The less pronounced presence of $\mathrm{SiO}_{2}$ polymorphs represented as $\alpha$-quartz and cristobalite was also indicated. Compared to the original perlite, the expanded one showed a marked increase in the amount of cristobalite present.

The phase composition tests were carried out at the characteristic points obtained in the thermal analysis and in the FTIR structural tests. Figures 11-14 show the diffraction patterns for the tested samples of Slovak perlite (SP1-SP3) and Hungarian (HP) ore. Figure 15 shows the diffractograms for ground vermiculite $(\mathrm{V})$.

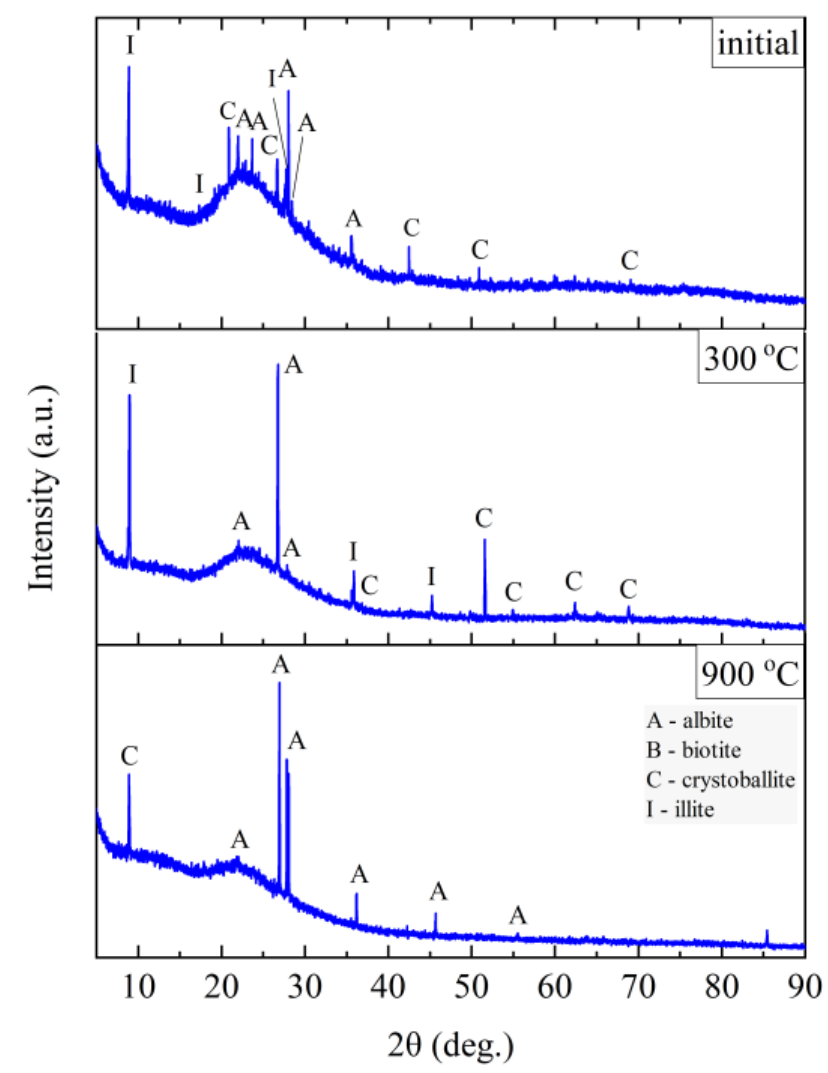

Figure 12. XRD diffractograms for Slovak perlite ore SP2. 


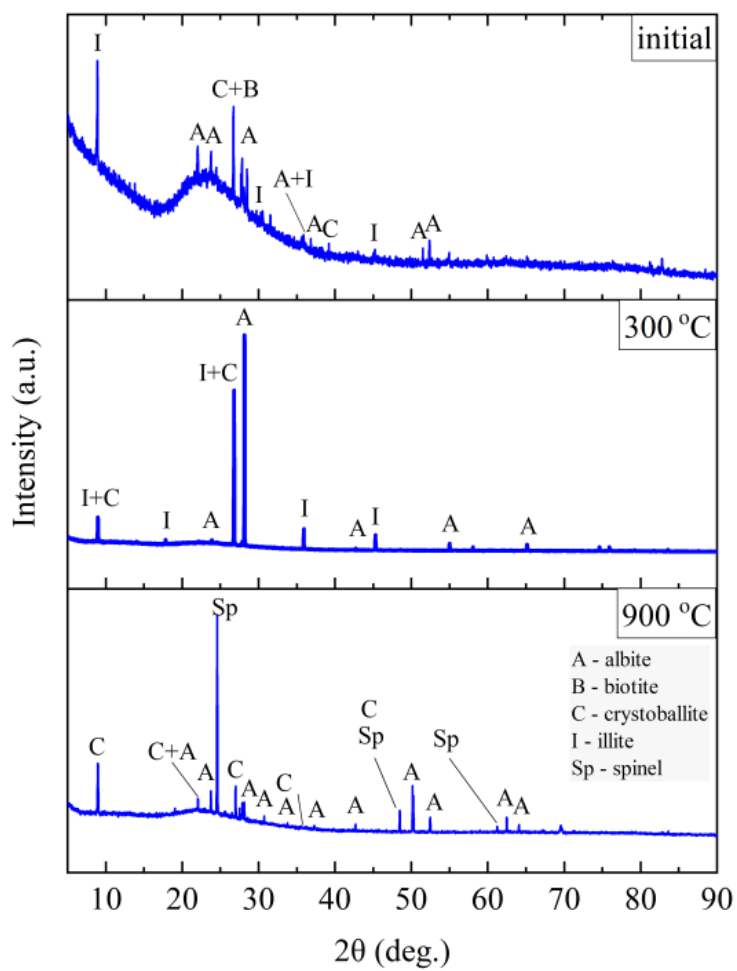

Figure 13. XRD diffractograms for Slovak perlite ore SP3.

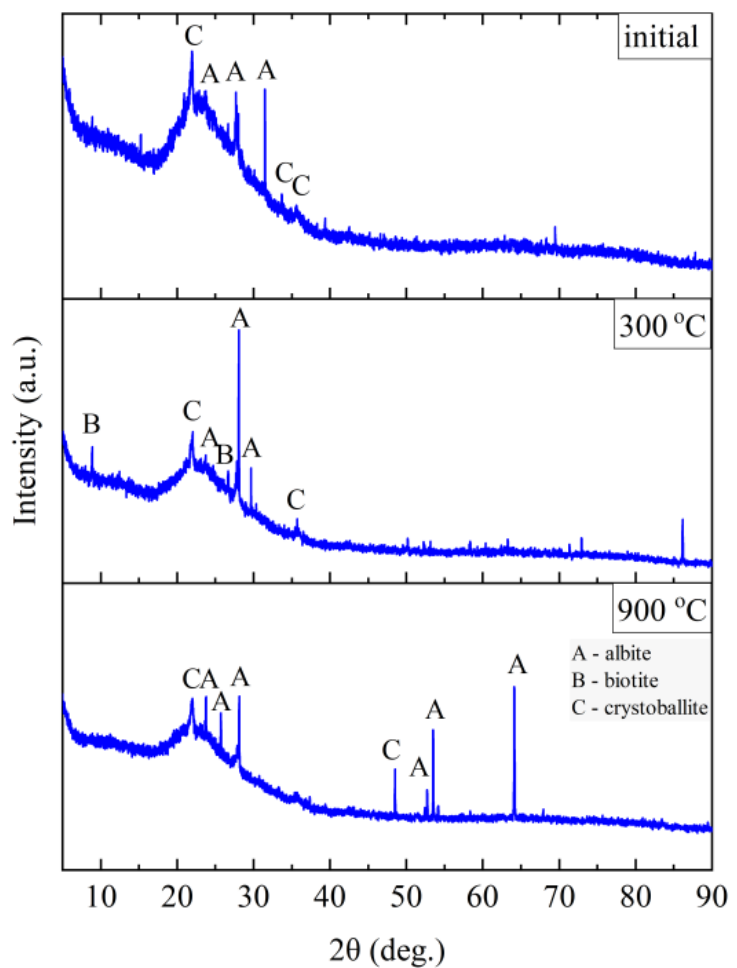

Figure 14. XRD diffractograms for Hungarian perlite ore HP. 


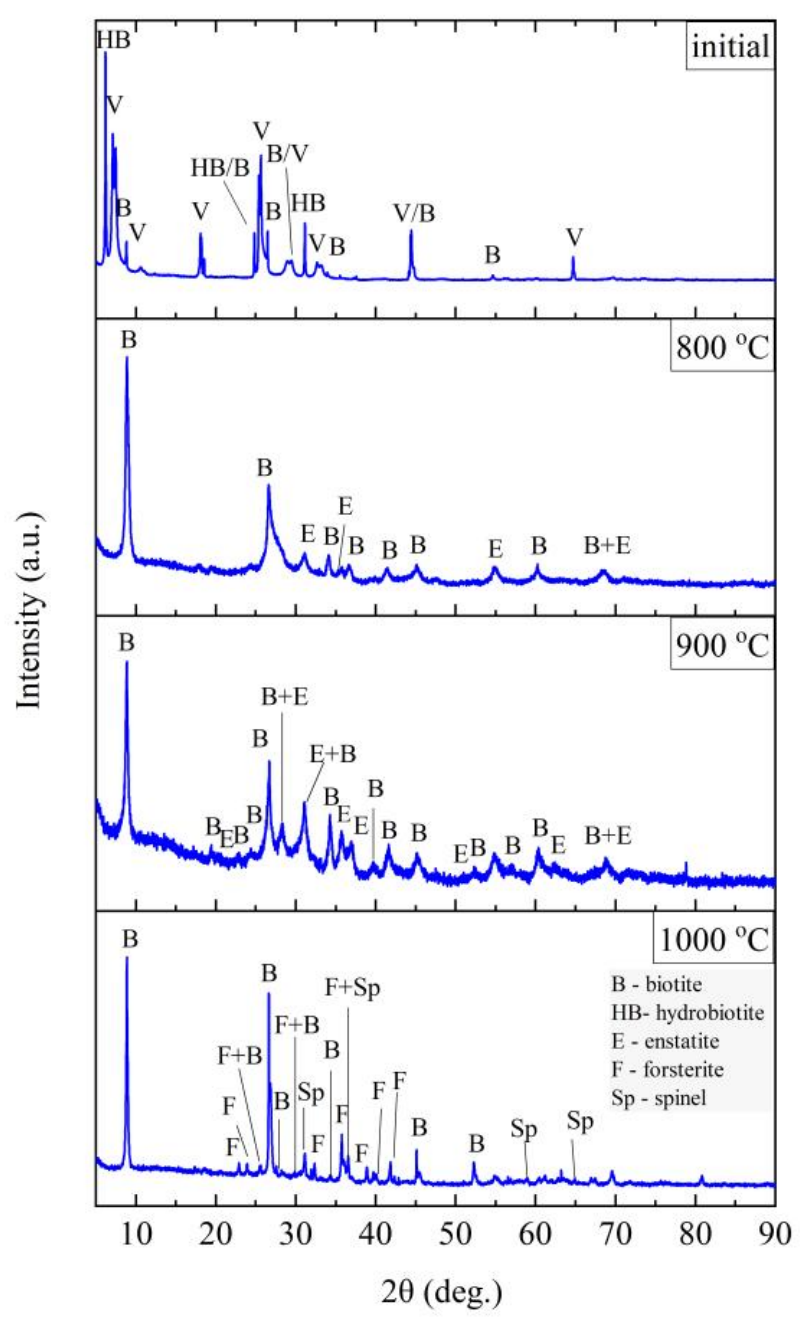

Figure 15. XRD diffractograms for vermiculite (V).

The finest fraction of Slovak perlite (SP1) in the initial state consists mainly of the amorphous phase-this is indicated by the presence of the so-called amorphous halo in the range of $2 \theta=18-30^{\circ}$, with visible inclusions of the crystalline phase represented by cristobalite (C), albite (A), illite (I), biotite (B), and calcium and aluminum silicates (S)-Figure 11. At the temperature above $300^{\circ} \mathrm{C}$, no changes in the phase composition were found, while above the temperature of $900{ }^{\circ} \mathrm{C}$, reflections from the crystalline phases disappear, and the sample consists only of the amorphous phase, which confirms the conclusions of the spectroscopic studies (Figure 6) regarding the disintegration of the structure. The mean fraction (SP2) and the coarsest fraction (SP3) have a phase composition similar to that of the SP1 sample. In addition to the amorphous halo, reflections related to the presence of albite (A), cristobalite (C), and illite (I) were identified, but no biotite (B) was found, which was probably screened entirely to the finest fraction (SP1). At a temperature above $300{ }^{\circ} \mathrm{C}$, the phase composition of the SP2 and SP3 samples also did not change, and at a temperature above $900^{\circ} \mathrm{C}$, two phases were identified in the SP2 perlite: albite (A) and cristobalite (C), while in the SP3 sample there was a clear increase in the amount of the amorphous phase and the formation of a new phase-spinel (Sp), most likely as a result of illite (I) decomposition [54].

The Hungarian perlite (HP) is the most homogeneous in terms of phase composition. The presence of the amorphous phase (amorphous halo), cristobalite (C), and albite (A) was recorded. During heating, at a temperature above $30{ }^{\circ} \mathrm{C}$, a decrease in the intensity of the amorphous halo associated with the amorphous phase is visible, and at the same time, 
an increase in the intensity of reflections from cristobalite $(\mathrm{C})$. Above $900{ }^{\circ} \mathrm{C}$, the presence of cristobalite (C) and albite (A) was found.

Three main phases were distinguished in the sample of the starting vermiculite after grinding: vermiculite, hydrobiotite, and biotite. As a result of heating the sample to the temperature of $700{ }^{\circ} \mathrm{C}$, the phase composition does not change. Only above $800{ }^{\circ} \mathrm{C}$ do the reflections from vermiculite disappear, which proves the decomposition of layered minerals, and on the diffractograms obtained for samples annealed at 800 and $900{ }^{\circ} \mathrm{C}$, two phases were distinguished-biotite and enstatite. Due to the clear changes in the structure noticed in the MIR (Mid-infrared) spectrum at $1000{ }^{\circ} \mathrm{C}$ (Figure 10), a phase analysis was performed for the sample annealed at this temperature. The results of the phase analysis (Figure 15) are consistent with the conclusions presented on the basis of spectroscopic studies. The clear shift in the position of the band associated with the $\mathrm{Si}-\mathrm{O}$ stretching vibration can be related to the appearance of iron-aluminum spinel, in which aluminum is present in coordination 6 with the formation of forsterite.

\subsection{Investigation of the Final Strength $\left(R_{m}^{t k}\right)$ of Moulding Sands with Mineral Additives}

The knock-out tests determine the susceptibility of the moulding sand to fragmentation under the influence of mechanical impact and removal from the mold (moulding sand) or casting (core sand) after the casting has cooled down to the knock-out temperature. Assessment of the knock-out properties of the moulding sand was carried out by determining the final strength, which allows capturing the first and second maximum strength (the first at a temperature of $200-300{ }^{\circ} \mathrm{C}$, the second in the range of $800-900{ }^{\circ} \mathrm{C}$ ). The research was aimed at showing the effect of the type of material on the obtained final strength depending on the annealing temperature. The figure shows the results of the determination for moulding sand without additives $(G)$, sand with the addition of the Slovak perlite ore (SP1-SP3), the Hungary perlite ore (HP), and the ground vermiculite (V).

Figure 16 shows that the moulding sand with a geopolymeric binder without additives (G) shows an increase in strength at $200{ }^{\circ} \mathrm{C}$ (first hardening).

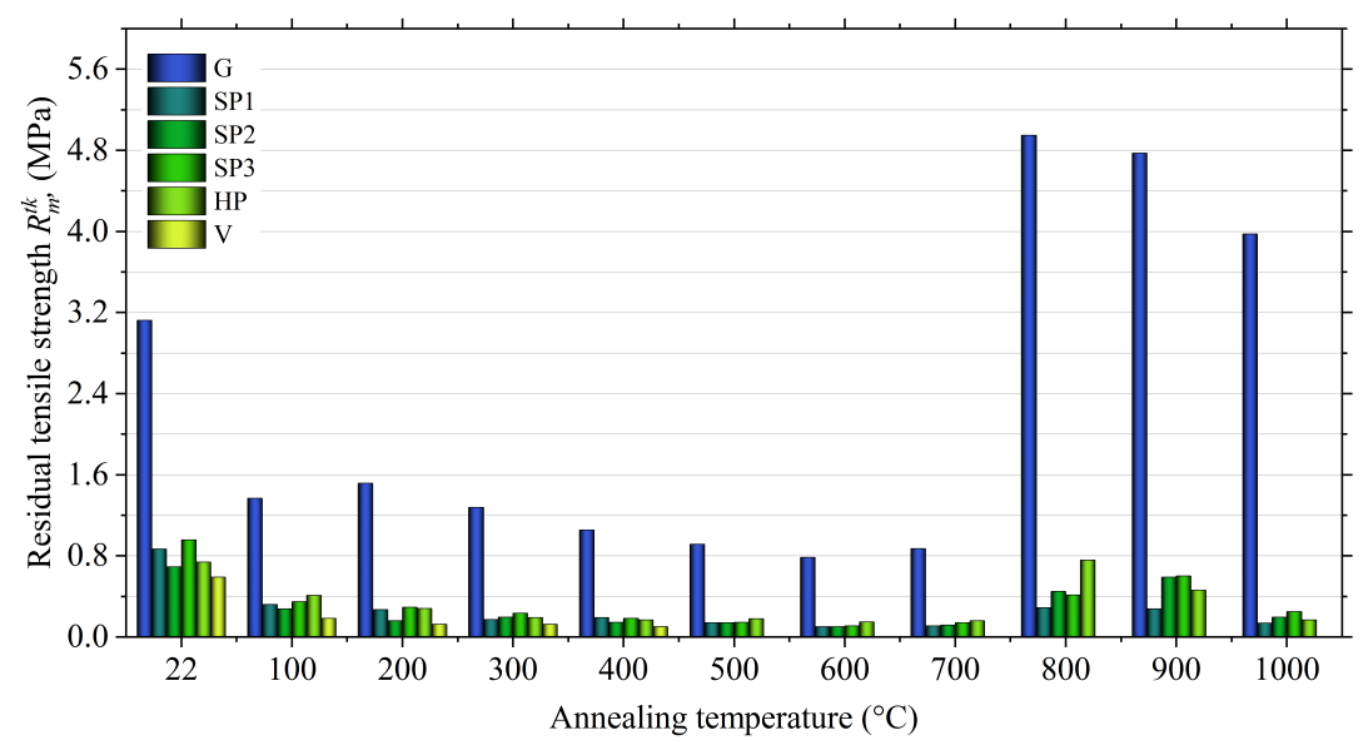

Figure 16. Final tensile strength $\left(R_{m}^{t k}\right)$ of moulding sands with $G e o p o l{ }^{\circledR}$ binder, depending on the type of additive.

The second maximum strength occurs at the temperature of $800{ }^{\circ} \mathrm{C}$ and is $4.95 \mathrm{MPa}$. The introduction of perlite ore into the moulding sand, regardless of the fraction size, has a positive effect on the reduction of the final strength, especially at higher temperature. The final tensile strength $\left(R_{m}^{t k}\right)$ with the addition of SP2 and SP3 Slovak perlite ore at the temperature of $800{ }^{\circ} \mathrm{C}$ decreases to about $0.4 \mathrm{MPa}$. Even better results are obtained by the moulding sand with the addition of the finest fraction (SP1), for which the final tensile 
strength value $R_{m}^{t k}=0.29 \mathrm{MPa}$ was obtained. In the case of the use of Hungarian perlite ore (HP), a visible decrease in final strength was also noted compared to the moulding sand without additives (G), but the strength at $800{ }^{\circ} \mathrm{C}$ is twice as high as in the case of moulding sand with the addition of Slovak pearlite ore of similar grain size (SP2). A better effect is obtained at a higher temperature, i.e., $900^{\circ} \mathrm{C}$, which, according to the authors, should be associated with a generally higher content of water accumulated in the structure of Hungarian perlite (3.29\% according to thermal analysis) released at a higher temperature. The desired effect of lowering the final strength obtained by introducing vermiculite into the moulding sand is achieved at a much lower temperature than in the case of perlite ore. The moulding sand with vermiculite (1.0 mass parts.), already at the temperature of $500{ }^{\circ} \mathrm{C}$, has a final tensile strength less than $0.01 \mathrm{MPa}$. This additive effect is due to the lower dehydroxylation temperature.

An important aspect from the technological point of view is the selection of the fraction of additives depending on the size of the matrix of the moulding sand. Proper adjustment of the size of the additive allows for better filling of voids between grains (pores). The greater degree of fragmentation means that they are able to be distributed throughout the entire volume of the moulding sand, which, when heated, gives the sand gives better results in terms of the number of microcracks and translates into a lower value of final strength.

The chemical composition of individual fractions may also influence the swelling process. The finer fraction of Slovak perlite is characterized by a higher $\mathrm{K}_{2} \mathrm{O} / \mathrm{Na}_{2} \mathrm{O}$ ratio. Perhaps it is an additional factor determining the reduction of the final strength of the moulding sand with SP1 ore.

Additionally, positive results are obtained with a lower share of vermiculite in the moulding sand (1.0 mass parts). As shown in previous studies [55], vermiculite added to the moulding sand in the initial form (nor ground) causes its destruction to an excessive degree.

\subsection{SEM Microscopic Imaging}

The microscopic tests were carried out to illustrate the mechanism of action of swelling additives in moulding sands with an inorganic binder, i.e., to capture microcracks resulting from increasing the volume of additives located in the inter-grain pores of the quartz matrix. Figures 17 and 18 show the images made with the use of an electron microscope (SEM) for selected samples of moulding sands subjected to temperature influence: with the addition of Slovak perlite (SP1) ore and ground vermiculite (V).

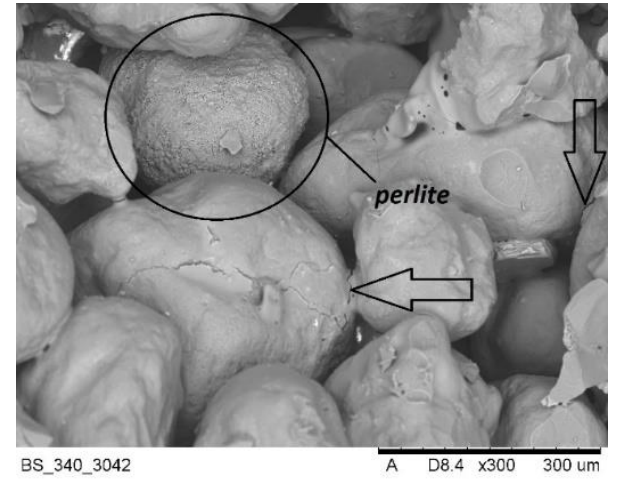

(a)

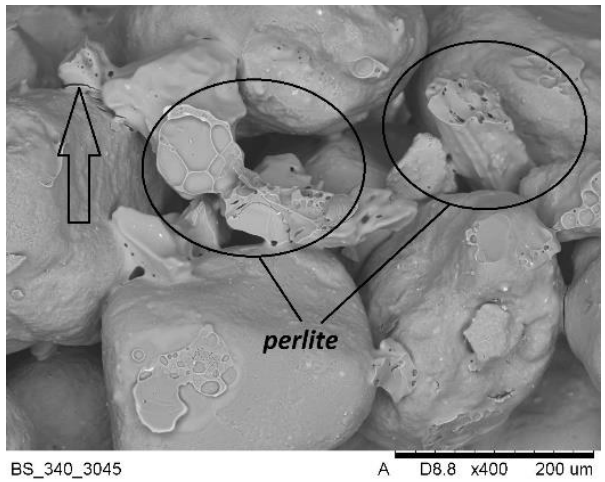

(b)

Figure 17. SEM imaging of moulding sand with SP1 perlite ore after annealing at $800^{\circ} \mathrm{C}$ : (a) magnification $300 \times$, (b) magnification $400 \times$. 


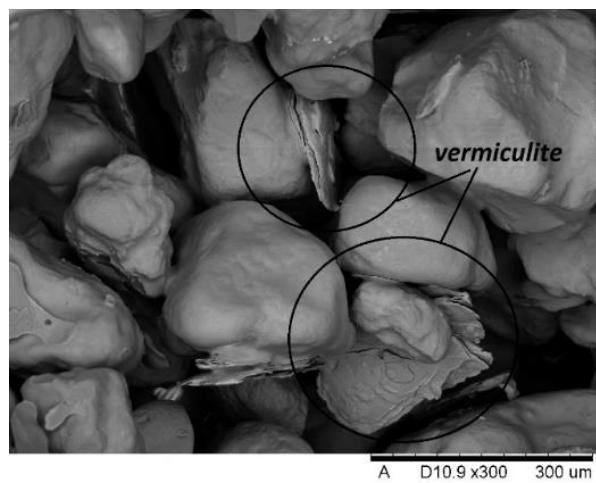

(a)

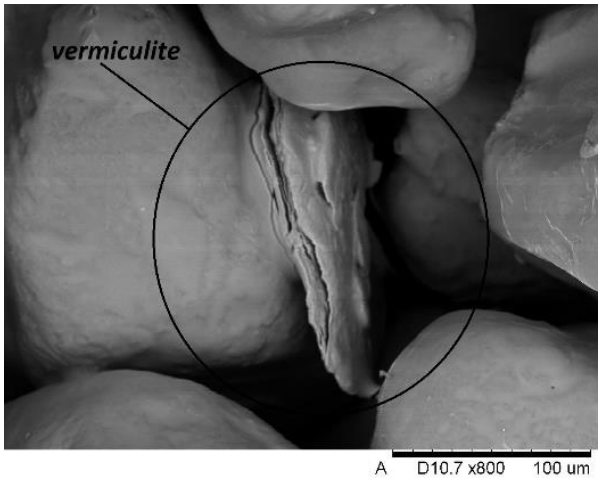

(b)

Figure 18. SEM imaging of moulding sand with vermiculite (V) after annealing at $800{ }^{\circ} \mathrm{C}$ : (a) magnification $300 \times$; (b) magnification $800 \times$.

The SEM photos presented above show that the additives introduced during the preparation of the moulding sand (perlite ore, vermiculite) are located between the grains of the moulding sand matrix. Under the influence of the high temperature of the casting alloy, the mineral additives swell, and the energy released in this process is transferred to the adjacent matrix grains, covered with a layer of binder, causing microcracks. The broken binder continuity reduces the final strength of the moulding sand, and thus contributes to the elimination of the technological inconvenience of poor knock-out. As a result, the efficiency of castings production is improved and energy and labor costs are reduced, without harming the natural environment.

\section{Conclusions}

Based on the research, the following conclusions were drawn:

- $\quad$ on the basis of the conducted thermal analysis, no significant correlation was found between the grading of the Slovak perlite ore (SP1-SP3) and the amount of water accumulated in its structure;

- the chemical composition, in particular the alkali ratio $\mathrm{K}_{2} \mathrm{O} / \mathrm{Na}_{2} \mathrm{O}$, and the size of the fraction may have a significant impact on the expandability of the pearlite ore. In the case of the finest fraction at a temperature above $900{ }^{\circ} \mathrm{C}$, it is possible to create an amorphous phase in the entire sample volume;

- in the finest fraction of Slovak perlite (SP1) at the temperature above $300{ }^{\circ} \mathrm{C}$, no changes in the phase composition were found, while above the temperature of $900{ }^{\circ} \mathrm{C}$, reflections from the crystalline phases disappear, and the sample consists only of the amorphous phase.

- $\quad$ at temperatures above $900{ }^{\circ} \mathrm{C}$, two phases were identified in the SP2 perlite: albite and cristobalite, while in the SP3 sample, the formation of a new phase-spinel was found, most likely as a result of illite decomposition.

- Hungarian perlite is characterized by greater stability in terms of phase composition during heating in the tested temperature range. Above $900{ }^{\circ} \mathrm{C}$, the presence of cristobalite and albite was found;

- $\quad$ vermiculite has a much higher water content than perlite ore-regardless of grain size and origin. The formation of the spatial structure characteristic of vermiculite, where the layers separate and there is a significant increase in volume, is observed at a temperature of approx. $500{ }^{\circ} \mathrm{C}$;

- it was shown that the structure of ground vermiculite does not change until a temperature of about $700{ }^{\circ} \mathrm{C}$. Only above $800{ }^{\circ} \mathrm{C}$ do the reflections from vermiculite disappear, which proves the decomposition of layered minerals, and the diffractograms obtained for samples annealed at 800 and $900{ }^{\circ} \mathrm{C}$ distinguish two phases-biotite and enstatite; 
- in the IR spectrum obtained for a sample of vermiculite annealed at the temperature of $1000{ }^{\circ} \mathrm{C}$, a clear shift in the band position related to the $\mathrm{Si}-\mathrm{O}$ stretching vibration was shown, which was interpreted as the appearance of an iron-aluminum spinel in which aluminum is in 6 coordination with the formation of forsterite;

- the processes of expanding perlite ore and exfoliating vermiculite have a positive effect on reducing the final strength of moulding and core sand with inorganic binders used in the foundry, eliminating technological inconveniences-poor susceptibility to knocking out. However, in the considered variants, the best effects of lowering the final strength of moulding sands with an inorganic geopolymer binder were obtained in the case of introducing the SP1 Slovak perlite ore in the finest fraction, which correlates well with the conclusion presented above.

Author Contributions: Conceptualization, A.B., K.K. and D.D.; methodology, A.B., K.K., D.D., M.S., B.G. and D.N.; investigation, A.B., K.K., D.D., M.L. and D.N.; data analysis, A.B., K.K., M.S., M.L.; writing-original draft preparation, A.B. and K.K.; writing—review and editing, A.B., K.K., M.S., B.G. All authors have read and agreed to the published version of the manuscript.

Funding: This research received no external funding.

Institutional Review Board Statement: Not applicable.

Informed Consent Statement: Not applicable.

Data Availability Statement: The data are contained within the article and/or are available on request from the corresponding author.

Conflicts of Interest: The authors declare no conflict of interest.

\section{References}

1. Bobrowski, A.; Holtzer, M.; Żymankowska-Kumon, S.; Dańko, R. Harmfulness assessment of moulding sands with a geopolymer binder and a new hardener, in an aspect of the emission of substances from the BTEX group. Arch. Metall. Mater. 2015, 60, 341-344. [CrossRef]

2. Drożyński, D.; Bobrowski, A.; Holtzer, M. Influence of the reclaim addition on properties of moulding sands with the Geopol binder. Arch. Foundry Eng. 2015, 15, 138-142. [CrossRef]

3. Lewandowski, J.L. Materials for Foundry Molds; Publishing House Akapit: Krakow, Poland, 1997.

4. Major-Gabryś, K.; Dobosz, S.M. The influence of the Glassex additive on technological and knock-out properties of the moulding sands with hydrated sodium silicate and new ester hardeners. Metall. Foundry Eng. 2011, 37, 33-40. [CrossRef]

5. Izdebska-Szanda, I.; Baliński, A. New generation of ecological silicate binders. Procedia Eng. 2011, 10, 887-893. [CrossRef]

6. Baliński, A. Influence of the modification method of hydrated sodium silicate on the effectiveness of changes in the final strength of moulding sand. Trans. Foundry Res. Inst. 2017, 57, 161-168. [CrossRef]

7. Dobosz, S.M.; Major-Gabryś, K. The mechanism of improving the knock-out properties of moulding sands with water glass. Arch. Foundry Eng. 2008, 8, 37-42.

8. Dobosz, S.M.; Major-Gabryś, K. Self-hardening moulding sands with water glass and new ester hardener. Inżynieria Mater. 2006, 27, 576-579.

9. Hutera, B.; Stypuła, B.; Kmita, A.; Bobrowski, A.; Drożyński, D.; Hajos, M. Effect of metal oxides nanoparticles on the tensile strength properties of foundry moulding sands with water glass. Giessereiforschung 2012, 64, 14-18.

10. Dobosz, S.M.; Major-Gabryś, K. Glassex-A new additive improving the knock-out properties of moulding sands with water glass. Archives of Foundry. 2004, 4, 63-68.

11. Wang, J.; Fan, Z.; Wang, H.; Dong, X.; Huang, N. An improved sodium silicate binder modified by ultra-fine powder materials. China Foundry 2007, 4, 026-030.

12. Bobrowski, A.; Stypuła, B.; Hutera, B.; Kmita, A.; Drożyński, D.; Starowicz, M. FTIR spectroscopy of water glass-The binder moulding modified by ZnO nanoparticles. Metalurgija 2012, 51, 477-480.

13. Bobrowski, A.; Kmita, A.; Starowicz, M.; Stypuła, B.; Hutera, B. Effect of Magnesium Oxide Nanoparticleson Water Glass Structure. Arch. Foundry Eng. 2012, 12, 9-12. [CrossRef]

14. Burkowicz, A. Expanded perlite-A thermal insulation material little known in Poland. Sci. J. Inst. Miner. Energy Econ. Pol. Acad. Sci. 2016, 96, 7-22.

15. Pichór, W.; Janiec, A. Thermal stability of expanded perlite modified by mullite. Ceram. Int. 2009, 35, 527-530. [CrossRef]

16. Samar, M.; Saxena, S. Study of chemical and physical properties of perlite and its application in India. Int. J. Sci. Technol. Manag. 2016, 5, 70-80. 
17. Żelazowska, E.; Pichniarczyk, P.; Najduchowska, M. Light glass crystalline aggregates from waste materials for the building materials industry. Mater. Ceram. 2014, 66, 321-330.

18. Żelazowska, E.; Pichniarczyk, P.; Sacha, S.; Zawiła, J.; Rybicka--Lada, J.; Marczewska, A. Obtaining glass-crystalline materials based on perlite ore and expanded perlite waste. Mater. Ceram. 2012, 64, 411-416.

19. Kaufhold, S.; Reese, A.; Schwiebacher, W.; Dohrmann, R.; Grathoff, G.H.; Warr, L.N.; Halisch, M.; Müller, C.; Schwarz-Schampera U.; Ufer, K. Porosity and distribution of water in perlite from the island of Milos, Greece. SpringerPlus 2014, 3, 598. [CrossRef] [PubMed]

20. Tsikouras, B.; Passa, K.S.; Iliopoulos, I.; Katagas, C. Micorstructural Control on perlite expansibility and geochemical balance with a novel application of Isocon analysis: An example from Milos Island Perlite (Greece). Materials 2016, 6, 80. [CrossRef]

21. Roulia, M.; Chassapis, K.; Kapoutsis, J.A.; Kamitsos, E.I.; Savvidis, T. Influence of thermal treatment on the water release and the glassy structure of perlite. J. Mater. Sci. 2006, 41, 5870-5881. [CrossRef]

22. Osacky, M.; Uhlik, P.; Kuchta, L. Experimental Alteration of Volcanic Glass; Acta Mineralogica-Petrographica, Abstract Series 5: Szeged, Hungary, 2006; Volume 86.

23. Balek, V.; Perez-Rodriguez, J.L.; Perez-Maqueda, L.A.; Subrt, J.; Poyato, J. Thermalbehaviour of ground vermiculite. J. Therm. Anzlysis Calorim. 2007, 88, 819-823. [CrossRef]

24. Poyato, L.; Perez-Maqueda, L.A.; Justo, A.; Balek, V. Emanation thermal analysis of natural and chemically-modified vermiculite. Clays Clay Miner. 2002, 50, 791-798. [CrossRef]

25. Lingya, M.; Xiaoli, S.; Yunfei, X.; Jingming, W.; Xiaoliang, L.; Jianxi, Z.; Hongping, H. The structural change of vermiculite during dehydration processes: A real-timein-situXRD method. Appl. Clay Sci. 2019, 183, 1-7. [CrossRef]

26. Marcos, C.; Arango, Y.C.; Rodríguez, I. X-ray diffraction studies of the thermal behaviour of commercial vermiculites. Appl. Clay Sci. 2009, 42, 368-378. [CrossRef]

27. Marcos, C.; Rodríguez, I. Expansion behaviour of commercial vermiculites at $1000{ }^{\circ}$ C. Appl. Clay Sci. 2010, 48, 492-498. [CrossRef]

28. Eaves, D. Sampling and analysis of crude vermiculite samples for possible asbestiform fibre and quartz content. IOM Consult. Rep. 2006, 924, 1130 .

29. Bagdassarov, N.; Ritter, F.; Yane, Y. Kinetics of perlite glasses degassing TG and DSC analysis. Glass Sci. Technol. 1999, 72, 277-290.

30. Austin, G.S.; Barker, J.M. Commercial perlite deposits of New Mexico and North America. In Proceedings of the New Mexico Geological Society 49th AnnualFall Field Conference, Socorro, Mexico, 19-22 October 1998; pp. 271-277.

31. Kozhukhova, N.I.; Chizhov, R.V.; Zhernovsky, I.V.; Strokova, V.V. Structure formation of geopolymer perlite binder vs. type of alkali activating agent. ARPN J. Eng. Appl. Sci. 2016, 11, 12275-12281.

32. Herskovitch, D.; Lin, I.J. Upgrading of raw perlite by a dry magnetic technique. Magn. Electr. Sep. 1996, 7, 145-161. [CrossRef]

33. Goodall, R.; Williams, C.; Fernie, J.A.; Clyne, T.W. Thermal Expansion and Stiffness Characteristics of a Highly Porous, FireResistant Composite Material. Available online: https://www.researchgate.net/publication/228871362_Thermal_Expansion_ and_Stiffness_Characteristics_of_a_Highly_Porous_Fire-Resistant_Composite_Material (accessed on 25 March 2021).

34. Hillier, S.; Marwa, E.M.; Rice, C.M. On the mechanism of exfoliation of vermiculite. Clay Miner. 2013, 48, 563-582. [CrossRef]

35. Koksal, F.; Gencel, O.; Kaya, M. Combined effect of silica fume and expanded vermiculite on properties of lightweight mortars at ambient and elevated temperatures. Constr. Build. Mater. 2015, 88, 175-187. [CrossRef]

36. Suvorov, S.A.; Skurikhin, V.V. Vermiculite-A promising material for high-temperature heat insulators. Refract. Ind. Ceram. 2003, 44, 186-187. [CrossRef]

37. Valáškowá, M.; Martynkowá, G. Vermiculite: Structural Properties and Examples of the Use. Clay Miner. Nat. Their Characterisation Modyfication Appl. 2012, 209-238. [CrossRef]

38. Rebilasová, S.; Peikertová, P.; Gröplová, K.; Neuwirthová, L. The influence of mechanical treatment of vermiculite on preparation of the composites vermiculite/ $\mathrm{TiO}_{2}$. In Proceedings of the NANOCON 2011 Conference Proceedings, Brno, Czech Republic, 21-23 September 2011.

39. Gailhanou, H.; Blanc, P.; Rogez, J.; Mikaelian, G.; Horiuchi, K.; Yamamura, Y.; Saito, K.; Kawaji, H.; Warmont, F.; Grenèche, J.M.; et al. Thermodynamic properties of saponite, nontronite, and vermiculite derived from calorimetric measurements. Am. Mineral. 2013, 98, 1834-1847. [CrossRef]

40. Handke, M. Crystallochemistry of Silicates, 2nd ed.; University Scientific and Technical Publishers of AGH: Krakow, Poland, 2008.

41. Campos, A.; Moreno, S.; Molina, R. Characterization of vermiculite by XRD and spectroscopic techniques. Earth Sci. Res. J. 2009, 13, 108-118.

42. Abidi, S.; Nait-Ali, B.; Joliff YFavotto, C. Impact of perlite, vermiculite and cement on the thermal conductivity of a plaster composite material: Experimental and numerical approaches. Compos. Part B 2015, 68, 392-400. [CrossRef]

43. Derkowski, A.; Drits, V.A.; McCarty, D.K. Nature of rehydroxylation in dioctahedral 2:1 layer clay minerals. Am. Mineral. 2012, 97, 610-629. [CrossRef]

44. Derkowski, A.; Drits, V.A.; McCarty, D.K. Rehydration in a dehydrated-dehydroxylated smectite in environment of low water vapor content. Am. Mineral. 2012, 97, 110-127. [CrossRef]

45. Harmon, R.S.; Wörner, G.; Goldsmith, S.T.; Harmon, B.A.; Gardner, C.B.; Lyons, W.B.; Ogden FLPribil, M.J.; Long, D.T.; Kern, Z.; Fórizs, I. Linking silicate weathering to riverine geochemistry-A case study from a mountainous tropical setting in west-central Panama. Geol. Soc. Am. Bull. 2016, 128, 1780-1812. [CrossRef] 
46. Varga, P.; Uhlik, P.; Lexa, J.; Šurka, J.; Bizovská, V.; Hudec, P.; Pálková, H. The influence of porosity on the release of water from perlite glass by thermal treatment. Mon. Chem. Chem. Mon. 2019, 150, 1025-1040. [CrossRef]

47. Erdoğan, S.T. Properties of Ground Perlite Geopolymer Mortars. J. Mater. Civil Eng. 2015, 27, 1-10. [CrossRef]

48. Rekaa, A.A.; Pavlovski, B.; Lisichkov, K.; Jashari, A.; Boev, B.; Boev, I.; Lazarova, M.; Eskizeybek, V.; Oral, A.; Jovanovski, G.; et al. Chemical, mineralogical and structural features of native and expanded perlite from Macedonia. Geol. Croat. 2019, 72, $215-221$. [CrossRef]

49. Mazoomi, F.; Jalali, M. Effect of vermiculite, nanoclay and zeolite on ammonium transport through saturated sandy loam soil: Columns experiments and modeling approaches. Catena 2019, 176, 170-180. [CrossRef]

50. Handke, M.; Sitarz, M.; Długoń, E. Amorphous SiCxOy coatings from ladder-like polysilsesquioxanes. J. Mol. Struct. 2011, 993, 193-197. [CrossRef]

51. Sitarz, M.; Jastrzębski, W.; Jeleń, P.; Długoń, E.; Gawęda, M. Preparation and structural studies of black glasses based on ladder-like silsesquioxanes. Spectrochim. Acta Part A 2014, 132, 884-888. [CrossRef]

52. Pérez-Maqueda, L.A.; Balek, V.; Payato, J.; Pérez-Rodriquez, J.L.; Šubrt, J.; Bountsewa, I.M.; Beckman, I.N.; Málek, Z. Stdy of natural and ion exchanged vermiculite by emanation thermal analysis, TG, DTA and XRD. J. Therm. Anal. Calorim. 2003, 71, 715-726. [CrossRef]

53. Handke, M. Vibration spectroscopy of silicates and the character of Si-O bonding in silicates. Sci. J. AGH 1984, 48.

54. De Araujo, J.H.; Da Silva, N.F. Thermal Decomposition of Illite. Mater. Res. 2004, 7, 359-361. [CrossRef]

55. Bobrowski, A. The Phenomenon of Dehydroxylation of Selected Mineral Materials from the Aluminosilicates Group as the Determinant Factor of the Knock-Out Improvement of Moulding and Core Sands with Inorganic Binder; Archives of Foundry Engineering; Polish Academy of Sciences: Gliwice, Poland, 2018. 